\title{
ESTUDO SEMIÓTICO DE PERCURSOS PASSIONAIS NO SAMBA-CANÇÃO
}

\author{
A Semiotic Study of Passional Courses Estúdios semióticos de trayectória pasional \\ In The Samba-Canção Music en samba-canção
}

\author{
Álvaro Antônio Caretta* \\ Universidade Federal de São Paulo, Escola de Filosofia, Letras e Ciências Humanas, \\ Departamento de Letras, Guarulhos, SP, Brasil
}

\begin{abstract}
Resumo: O universo da música popular brasileira é repleto de elementos passionais, mas o gênero que fez da paixão o seu estilo foi o samba-canção. Este artigo, com base nas propostas da semiótica, aborda as paixões no discurso desse gênero musical, procurando compreender como os efeitos de sentido passionais são elaborados em suas composições. Para isso, tendo como orientação o consagrado ensaio De la colère, de A. J. Greimas, é realizado um recorte, constituído pelas canções As rosas não falam (1976), Volta (1978), Quem há de dizer (1972), Atiraste uma pedra (1958), Vingança (1972) e Castigo (1978). A observação de percursos passionais serve como estratégia para realizar uma leitura desse gênero musical. $\mathrm{O}$ artigo trabalha, então, com as paixões que determinam o percurso passional da vingança, contido no percurso da cólera, a fim de revelar o tratamento dado a elas nas composições do samba-canção.
\end{abstract}

Palavras-chave: Discurso. Semiótica. Canção popular. Paixões. Samba-canção.

\begin{abstract}
The universe of Brazilian popular music is full of passionate elements, but the genre that used the passion as style was the samba-canção (in English, literally "samba-song"). In this paper, based on semiotic notions, we analyse the passions in the discourse of this musical genre, trying to understand how the passionate sense effects in its composition are elaborated. In this regard, guided by A. J. Greimas renowed essay De la colère, we made an excerpt consisted by the songs As rosas não falam (1976), Volta (1978), Quem há de dizer (1972), Atiraste uma pedra (1958), Vingança (1972) e Castigo"(1978). When observing passional courses, they serve as strategy to perform a reading of that musical genre. In brief, we work with the passions, which determine the passional course of revenge, inserted in the cholera course, in order to reveal the treatment provided to them in samba-canção's compositions.
\end{abstract}

Keywords: Discourse. Semiotics. Popular song. Passions. Samba-canção.

Resumen: El universo de la música popular brasileña es lleno de elementos pasionales, pero el género que hace de la pasión su estilo es el samba-canção. Este artículo, basado en propuestas de semiótica, enfoca pasiones del discurso de ese género musical, buscando comprender cómo los efectos pasionales de sentido son elaborados en sus composiciones. Para ello, bajo la guía del reconocido ensayo De la colère, de A. J. Greimas, es realizado un recorte constituido por las canciones As rosas não falam (1976), Volta (1978), Quem há de dizer (1972), Atiraste uma pedra (1958), Vingança (1972) y Castigo (1978). La observación de recursos pasionales sirve cómo estrategia para una lectura de ese género musical. Entonces, el artículo trabaja con pasiones que determinan la trayectoria pasional de venganza, de la trayectoria de rabia, para revelar el tratamiento a ellas dirigido en composiciones del samba-canção.

Palabras clave: Discurso. Semiótica. Canción popular. Pasiones. Samba-canção.

* Doutor em Semiótica e Linguística Geral. Professor Adjunto do Departamento de Letras da UNIFESP. ORCID: https://orcid.org/0000-0001-6580-0226. E-mail: alcaretta@yahoo.com.br. 
Inicialmente, os estudos semióticos abordaram o percurso do sujeito tendo em vista as transformações narrativas determinadas pelo /fazer/. Pressupostas a esse /fazer/ estão as modalidades que constituem a competência modal do sujeito, ou seja, o seu /ser/. O /fazer/ do sujeito atua como elemento transformador ao promover alterações em sua própria competência modal, estabelecendo um novo /ser/. Concebe-se, assim, um percurso em que as relações entre o /ser/ e o /fazer/ são determinadas por uma sintaxe passional (FONTANILLE, 1986), orientada pelas variações tensivas nas instâncias do nível profundo e estabelecida no nível discursivo por uma sequência de figuras passionais.

Segundo Edward Lopes (1989/90, p.154-160), as paixões no discurso são compreendidas não como uma estrutura que se esgota em si mesma, mas como uma "força" determinante na progressão do percurso passional do sujeito, no qual o /ser/ e o /fazer/ coabitam intrinsicamente. O /fazer/ revela-se em forma de ato como uma exteriorização do /ser/, enquanto este é a potência que o orienta.

A paixão, interpretada como potência, impele o sujeito à ação por meio da projeção de um percurso narrativo. Desse ângulo, a paixão é vista em seu aspecto incoativo como tendência e o resultado desse percurso revela-a em seu aspecto terminativo. Esse estado final pode ainda, dependendo do arranjo modal instituído, reassumir o caráter incoativo e dar sequência ao percurso passional.

O ritmo desse percurso, depreendido a partir da sequência das figuras passionais, reflete o movimento tensivo que o ativa. Ele é sempre de ordem juntiva, determinado pelos movimentos de atração e repulsão presentes na relação entre o sujeito e o objeto ou entre sujeitos. Em se tratando de um discurso como a canção, o ritmo discursivo revelase também no componente melódico que, enquanto fenômeno inscrito no tempo, estabelece-se pelos movimentos de aceleração e desaceleração da melodia, cuja gênese está nas oscilações tensivas inerentes à progressão do percurso passional do sujeito.

Este trabalho tem como objetivo estudar um conjunto de canções pertencentes ao gênero samba-canção e analisar, com base nas propostas da semiótica das paixões, como os efeitos de sentido passional são trabalhados nas composições. Frente à grande variedade de paixões que o samba-canção apresenta, a observação dos percursos passionais revela-se uma boa estratégia metodológica para se realizar uma leitura desse gênero musical. Em seu consagrado ensaio De La Colère (1983), Greimas estudou os vários estados passionais que compõem o percurso da cólera, assim como as variações que se estabelecem a partir dele. Como metodologia, seguiremos, baseados neste artigo seminal, um roteiro das paixões que determinam o percurso passional da vingança, contido no percurso da cólera, por meio das canções "As rosas não falam" (1976), "Volta" (1978), "Quem há de dizer" (1972), “Atiraste uma pedra” (1958), "Vingança" (1972) e "Castigo" (1978), com a finalidade de estudar semioticamente o tratamento linguístico e melódico dado a esses percursos passionais nesses clássicos do samba-canção. 
Como a canção é um gênero sincrético composto pelas linguagens verbal e musical, para estudar a imagem do enunciador nos enunciados, é preciso observar o seu modo de dizer, analisando as estratégias que ele utiliza para compatibilizar os elementos linguísticos e melódicos. Para isso, lançamos mão das propostas do semioticista Luiz Tatit, que desenvolveu um modelo bastante produtivo para o estudo da significação na canção popular.

Tatit procurou compreender como se estabelece a produção do sentido na canção. Nessa empreitada, seus estudos voltaram-se para uma investigação das estruturas fundamentais que determinam as marcas estabelecidas na superfície do discurso, no intuito de determinar parâmetros homogêneos para a análise da relação entre letra e melodia.

Nesse sentido, a tensividade fórica, estabelecida nas estruturas profundas do discurso por uma proto-sintaxe, vai determinar leis comuns tanto para a letra quanto para a melodia. A atração tensiva inerente à relação sujeito-objeto, quando determinada narrativamente pela conjunção, estabelece-se melodicamente pela reiteração dos motivos (concentração) e quando pela disjunção, promove uma valorização do percurso melódico em busca da conjunção (extensão). A concepção do nível missivo no percurso gerativo da canção baseada nas pesquisas de Zilberberg em "Pour introduire le faire missif" (1988) estabelece os valores remissivos (retenções) e os emissivos (distensões) como protótipos dos programas narrativo e melódico que serão trabalhados na superfície pelo sujeito da enunciação. Tendo em vista o caráter eminentemente entoativo da canção, a releitura que Tatit faz dos estudos sobre a silabação em Saussure, Hjelmslev e Zilberberg é muito pertinente pelo fato de estabelecer uma relação direta entre o nível fórico e o plano de expressão da canção.

Em síntese, o modelo apresentado por Tatit propõe três tipos de integração entre a melodia e a letra: a tematização, a passionalização e a figurativização. $\mathrm{O}$ "modo de dizer" do enunciador nas canções pode ser compreendido pela manipulação dessas três estratégias que, em uma análise discursiva, devem ser compreendidas tendo em vista as condições de enunciação, para que assim adquiram valor discursivo.

A passionalização propicia ao enunciador apresentar estados passionais na canção. Nela, a melodia explora o percurso melódico com grandes curvas e saltos ascendentes e descentes, investindo na duração das notas que incidem nos sons vocálicos, recursos esses que desaceleram a melodia.

\footnotetext{
Uma integração baseada no restabelecimento dos elos perdidos. Na letra, temos em geral a descrição dos estados passionais que acusam a ausência do outro, o sentimento (presente, passado ou futuro) de distância, de perda, e a necessidade de reconquista, enquanto na melodia manifestam-se direções que exploram amplamente o campo de tessitura (de praxe mais dilatado), servindo-se mais uma vez de decisões musicalmente complementares: desaceleração do andamento, valorização das durações vocálicas [...] (TATIT; LOPES, 2008, p. 21).
} 
A tematização é um processo em que a duração das vogais é reduzida e promovese a reiteração dos motivos rítmico-melódicos, produzindo uma progressão melódica mais veloz, segmentada pelos ataques das consoantes. A tematização melódica é compatível com letras que descrevem sentimentos ou acontecimentos eufóricos. Ela também define gêneros musicais como o maxixe, o samba, a marcha etc., tendo em vista as particularidades musicais de cada um desses ritmos.

\begin{abstract}
Uma integração baseada num processo geral de celebração. Na letra, exalta-se a mulher desejada, a terra natal, a dança preferida, o gênero musical, uma data, um acontecimento, enquanto na melodia manifesta-se uma tendência para a formação de motivos e temas a partir de decisões musicalmente complementares: aceleração do andamento, valorização dos ataques consonantais e acentos vocálicos (consequentemente, redução das durações) e procedimentos de reiteração (TATIT; LOPES, 2008, p.19).
\end{abstract}

O processo de figurativização caracteriza-se pela submissão da melodia às inflexões da fala. A letra apresenta os interlocutores por meio dos dêiticos de pessoa, "eu-tu"; de tempo, "aqui"; e de espaço, "agora", que determinam o momento da enunciação e estabelecem as referências para outras categorias.

Esse processo geral de programação entoativa da melodia e de estabelecimento coloquial do texto pode ser denominado figurativização por sugerir ao ouvinte verdadeiras cenas (ou figuras) enunciativas. Pela figurativização captamos a voz que fala no interior da voz que canta (TATIT; LOPES, 2008, p. 21).

A figurativização é um processo que se aproxima da entonação da fala cotidiana, criando o efeito figurativo de situação locutiva.

Baseados nessas indicações, consideramos que a canção reconstrói em seu interior uma compatibilidade com a qual estamos acostumados a conviver: tudo que enunciamos já vem com melodia. Trata-se, portanto, da produção de um efeito figurativo de locução (TATIT; LOPES, 2008, p.18).

Segundo Tatit e Lopes (2008, p. 21-22), dois elementos são fundamentais na criação do efeito de situação locutiva: os dêiticos e os tonemas. Elementos linguísticos que marcam as posições enunciativas de tempo e de espaço na letra da canção, os dêiticos aparecem nos pronomes demonstrativos, advérbios, vocativos, imperativos etc. Os tonemas, inflexões da voz que finalizam as frases entoativas, obedecem a três movimentos melódicos: a descendência, que figurativiza uma finalização asseverativa, a ascendência, que sugere uma complementação compensatória, e a sustentação, que promove a continuidade.

É importante observar que a figurativização sempre está presente também nas canções temáticas e passionais. Como essas três estratégias persuasivas aparecem em caráter dominante, recessivo ou residual, nas canções figurativas, a figurativização se manifesta de maneira dominante, predominando a voz que fala sobre a voz que canta. Já nas canções passionais e temáticas, a figurativização está sempre presente como recessiva ou residual, submetendo a voz que fala à voz que canta. 
Particularmente no samba-canção, poderemos observar a onipresença da passionalização, que propicia ao enunciador apresentar estados passionais. Nela, a melodia explora o percurso melódico com grandes curvas e saltos ascendentes e descentes, investindo na duração das notas que incidem nos sons vocálicos, recursos esses que desaceleram a melodia. Quanto maior a duração das frequências, maior a tensividade. Para criar esse efeito de sentido na adequação entre os componentes melódico e linguístico, as vogais adquirem extrema importância, pois somente esses sons podem ter a sua duração ampliada. A frequência melódica já possui uma tensão inerente; se prolongada, ela se intensifica e, no caso de ela estar em ascensão na tessitura, apresenta uma maior carga de concentração de intensidade, recurso muito usado no samba- canção para enfatizar a carga passional de suas melodias.

O enunciador, ao optar pela persuasão passional, elabora um conjunto de relações linguísticas e melódicas na canção que vão assegurar a paixão no discurso. A canção convence pela identificação com os seus sentimentos, garantindo a eficácia de seu discurso.

\section{O SENTIMENTO DE FALTA}

A falta pode originar-se de um estado de espera simples, em que o sujeito (S1) deseja que outro sujeito (S2) mantenha a conjunção daquele com o objeto-valor: S1

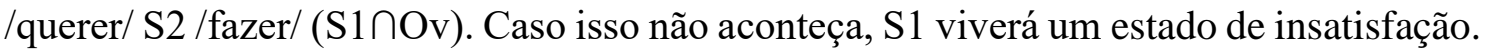
A gênese do sentimento de falta pode ser também uma espera fiduciária: S1 /crer/ S2

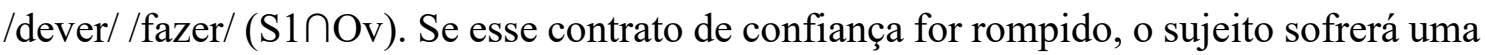
decepção.

Em ambos os casos, os sentimentos de insatisfação ou decepção são modalizados por um /querer-ser/ em conflito com um /saber-não ser/. No plano narrativo, são determinados por uma não-conjunção e possuem uma aspectualidade terminativa. Esses sentimentos podem atenuar-se dando lugar a uma resignação ou transformar-se em um sentimento de falta, que possui uma aspectualidade incoativa - /querer/ - que modaliza um programa de liquidação da falta.

Essa questão foi desenvolvida por Greimas e Fontanille, em Sémiotique des passions (1991, p.202), quando apresentada a noção de attachement ${ }^{1}$. Para que exista a falta, é imprescindível um apego do sujeito pelo objeto e a intensidade daquela será proporcional à deste. $\mathrm{O}$ fato de o sujeito estar em disjunção com o objeto, mas ao mesmo tempo apegado ao valor, estabelece o sentimento de falta. Sendo o sujeito dependente do objeto, a única possibilidade para ele estabilizar-se passionalmente é executar um programa narrativo de liquidação da falta.

O sentimento de falta é um tópico fundamental no universo temático do sambacanção. Para compreendê-lo melhor, analisaremos, agora, duas canções representativas desse gênero musical: "As rosas não falam" (1976), de Cartola, e "Volta" (1978), de Lupicínio Rodrigues.

\footnotetext{
1 "Apego", na tradução para o português.
} 


\title{
AS ROSAS NÃO FALAM
}

\author{
Bate outra vez \\ Com esperanças o meu coração \\ Pois já vai terminando o verão, enfim! \\ Volto ao jardim \\ Com a certeza que devo chorar \\ Pois bem sei que não queres voltar para mim \\ Queixo-me às rosas, \\ Mas que bobagem \\ As rosas não falam \\ Simplesmente as rosas exalam \\ O perfume que roubam de ti, ai! \\ Devias vir \\ Para ver os meus olhos tristonhos \\ E quem sabe sonhavas meus sonhos, por fim.
}

O primeiro verso - "Bate outra vez" - denota o retorno de um estado passional já vivido anteriormente. A esperança que novamente invade o sujeito, figurativizado metonimicamente por "meu coração", possui uma aspectualidade incoativa, pois é modalizada por um /querer-ser/ que promove a abertura de um simulacro passional.

O aspecto temporal, figurativizado por "já vai terminando o verão", mais do que a passagem do tempo, expressa a chegada do momento oportuno para que renasça a esperança, momento esse bastante aguardado, como se percebe na interjeição "enfim!?".

A incoatividade estabelecida pela esperança - /querer-ser/ - induz o sujeito a realizar um programa narrativo - "volto ao jardim". No entanto, ele está ciente de que sofrerá uma nova decepção - "Pois bem sei que não queres voltar/ Para mim". Esse conflito entre o /querer-ser/ e o /saber-não ser/ anuncia o sentimento de falta.

O espaço, figurativizado como "jardim", delimita a zona de flutuação da tensão passional, resultante dos estados passionais por que o sujeito já passou. Pode-se pressupor que ele já estivera em conjunção com o objeto e agora vive uma disjunção, devido ao fato de S2, figurativizado como "tu", ser modalizado por um /não-querer/, fato do qual o sujeito é plenamente consciente.

O conflito entre o / querer-ser/ e o /saber-não ser/ determina a aspectualidade do simulacro passional. $\mathrm{O}$ aspecto incoativo é instaurado pelo /querer/ - "Bate outra vez" -, porém o /saber/ - "Pois bem sei" - recobre todo o percurso passional do sujeito fazendo com que as marcas de aspectualização encontrem-se, a priori, marcadas pela terminatividade. A abertura do simulacro no início da canção serve para que o sujeito expresse o seu lamento.

Em seu ensaio De la nostalgie: Etude de sémantique lexicale (1988), Greimas apresenta o lamento como estado doloroso, marcado por um estado de consciência. $\mathrm{Na}$ canção, o lamento é figurativizado pela expressão "Queixo-me às rosas". O sujeito (S1) deseja exteriorizar seu sentimento de falta, mas a incoatividade estabelecida pelo /querer/ é novamente interrompida por um /saber/ - "mas que bobagem, as rosas não falam". 
Além de não possibilitar ao sujeito expressar o seu lamento, as rosas possuem uma carga semântica - "Simplesmente as rosas exalam/ O perfume que roubam de ti"- que intensifica o sentimento de falta, cuja tensão passional vem depositada na interjeição “Ai!".

O sujeito sofre - "olhos tristonhos" - porque tem consciência da impossibilidade de uma nova conjunção. No entanto, devido ao apego, sempre lhe resta uma esperança "e quem sabe sonhavas meus sonhos" - que, por meio de um /querer/ renovado, institui um ciclo contínuo em que se sucedem as figuras de esperança e decepção.

Essas modulações introduzem um ritmo percebido na melodia da canção que investe nas oscilações melódicas e valoriza a tonalização, prolongando e sustentando as notas principais de cada curva ${ }^{2}$. Esse recurso, juntamente com a duração das pausas, institui a desaceleração como ritmo preponderante.

No final de cada fraseado melódico, ocorre uma síncope descendente que, apesar de acelerar a melodia, acaba conduzindo-a para um repouso na nota mais grave. A desaceleração também se apresenta na extensa gradação ascendente que vai desembocar na execução da interjeição “Ai!", que figurativiza a carga passional resultante da oscilação entre a esperança e a decepção.

A melodia da última parte da canção é uma repetição da primeira. Isso confirma a opção pela desaceleração, criando um tempo que possibilita ao sujeito cultivar o seu sentimento de falta e viver o conflito entre a disjunção com o objeto e a conjunção com o valor, que sempre retorna à sua memória no perfume das rosas.

A canção "Volta", de Lupicínio Rodrigues, também exemplifica muito bem a presença do sentimento de falta no samba-canção. Ela expõe o apelo desesperado de um sujeito em disjunção com o objeto.

\section{VOLTA}

Quantas noites não durmo

A rolar-me na cama

A sentir tanta coisa

Que a gente não sabe explicar quando ama

O calor das cobertas

Não me aquece direito

Não há força no mundo

Que possa afastar esse frio em meu peito

Volta

Vem viver outra vez a meu lado

Eu não posso dormir sem teu braço

Pois meu corpo está acostumado.

\footnotetext{
${ }^{2}$ Propõe-se que o leitor ouça as canções para acompanhar as análises, já que o contato com a obra é insubstituível. Caso queira visualizar a melodia, sugerimos o acompanhamento de uma partitura. Há vários sites que as dispõem.
} 
O sujeito vive o sentimento de falta, com o agravante de ser prolongado, como mostra a aspectualização temporal "Quantas noites". O embaraço passional que o sujeito vive, figurativizado por "a rolar-me na cama" e "a gente não sabe explicar", justifica-se pelo apego que o prende ao objeto. Se for pressuposto um estado anterior, no qual o sujeito vivera um estado de conjunção, pode-se pensar as seguintes transformações: dormir - não dormir, conjunção - disjunção, emissivo - remissivo, continuidade descontinuidade.

Além da inquietude, o sujeito vive um estado de insatisfação, também consequência de seu sentimento de falta "O calor das cobertas/ Não me aquece direito/ Não há força no mundo/Que possa afastar/ Esse frio em meu peito”. Esse estado passional pode ser representado pelas seguintes oposições: calor x frio, conjunção x disjunção, emissivo $\mathrm{x}$ remissivo, continuidade $\mathrm{x}$ descontinuidade.

"O calor das cobertas" não é o mesmo que o sujeito usufruía, sendo insuficiente para estabilizá-lo passionalmente. Ele é consciente de que não há outra alternativa para acabar com seu sentimento de falta a não ser uma nova conjunção. Assim, o apego determina o estado passional, modalizando a junção pelo /dever-ser/ (necessidade).

$\mathrm{O}$ aspecto melódico dessa parte, caracterizado por gradações descendentes em graus imediatos, ao valorizar as durações e explorar a extensão passional, acentua os aspectos remissivos presentes na letra. Notamos um salto que acelera a melodia, porém ele serve como impulso para uma outra gradação, o que reforça a opção pela desaceleração ao repetir o fraseado melódico anterior.

$\mathrm{Na}$ segunda parte da canção irrompe o apelo do sujeito: "Volta/ Vem viver outra vez a meu lado/ Eu não posso dormir sem teu braço/ Pois meu corpo está acostumado". O apelo, expresso com toda a sua intensidade pela forma verbal "Volta", direciona a intensidade do /querer/ ao objeto, agora transformado em sujeito S2. S1 clama, porque precisa de uma nova conjunção, no entanto delega o/fazer/ a S2. Esse apelo busca restituir todo um passado passional que o sujeito perdeu, a fim de restabelecer uma continuidade interrompida.

A nova conjunção desejada pelo sujeito é figurativizada pela expressão adverbial "ao meu lado" que expressa a aspectualização espacial da junção. Em oposição ao distanciamento, responsável pelos valores remissivos, a proximidade espacial retomaria os valores emissivos.

O sujeito tem plena consciência de seu apego e da necessidade da conjunção, sendo modalizado pelo /saber/ de que só poderá retomar a continuidade com a presença física do objeto, figuratizado metonicamente por "teu braço"3. O sujeito declara, então, a sua dependência, pois o objeto é parte dele.

Vimos que a melodia da primeira parte da canção, por meio da desaceleração explora os valores remissivos, mas essa duração excessiva cria a necessidade de valores emissivos.

\footnotetext{
${ }^{3}$ Zilberberg (1988, p.107) discorre a respeito de uma semiótica da identificação, na qual existe uma relação de identidade entre o sujeito e o objeto que seria a razão da dependência do sujeito. Uma cisão nessa relação perturbaria a identidade do sujeito e consequentemente o desestabilizaria passionalmente.
} 
Na segunda parte, a aceleração promovida pela transposição melódica na execução do apelo faz desse instante o mais representativo da canção. Nesse ponto, os valores remissivos são rejeitados, dando lugar ao fazer emissivo - / parada da parada/.

Porém, a aceleração imprimida por essa transposição é compensada por uma gradação descendente que retoma os valores remissivos. O sentimento de falta ainda persiste, pois o apelo não é suficiente para a retomada da continuidade, que só se efetuaria por meio de uma nova conjunção com o objeto.

\subsection{A RESIGNAÇÃO}

Nas duas canções anteriores, o sujeito vive o sentimento de falta, devido à necessidade de conjunção com o objeto. No entanto, esse sentimento pode não chegar a existir, caso o sujeito, ainda que insatisfeito, aceite resignadamente a não-conjunção. Neste caso, segundo Greimas (1983, p.234), a insatisfação se atenua pouco a pouco tornando-se resignação.

A questão que pretendemos abordar aqui é como o sujeito se torna resignado e não vive o sentimento de falta, aceitando esse estado de não-conjunção com o objeto. A fim de compreendermos essa questão, tomaremos como exemplo a canção "Quem há de dizer” (1972), de Lupicínio Rodrigues e Alcides Gonçalves.

\section{QUEM HÁ DE DIZER}

Quem há de dizer

Que quem você está vendo

Naquela mesa bebendo

É o meu querido amor

Repare bem que toda vez que ela fala

Ilumina mais a sala

Do que a luz do refletor

O cabaret se inflama

Quando ela dança

E com a mesma esperança

Todos lhe põem o olhar

E eu, o dono,

Aqui no meu abandono

Espero, louco de sono,

O cabaret terminar

Rapaz! leve essa mulher contigo

Disse uma vez um amigo

Quando nos viu conversar

Vocês se amam

E o amor deve ser sagrado

$O$ resto deixa de lado

Vá construir o seu lar 


\author{
Palavra! Quase aceitei o conselho \\ O mundo, este grande espelho, \\ Que me fez pensar assim \\ Ela nasceu com o destino da lua \\ Pra todos que andam na rua \\ Não vai viver só pra mim.
}

O sujeito cria um simulacro no qual relata a um interlocutor a sua narrativa passional, caracterizada pela duração de um estado de resignação frente à não-conjunção com o objeto. A aspectualidade espacial desse simulacro revela, por meio do distanciamento - "naquela mesa bebendo" -, a não-conjunção.

Inicialmente é apresentado um discurso de estetização do objeto - "ela" -, instruindo-lhe um /saber/ e um /poder/ /fazer/ ao ressaltar a sua competência. O processo de estetização, segundo Zilberberg (1988, p. 111), tem como característica tornar o objeto ativo e o sujeito passivo: "Toda vez que ela fala/ Ilumina mais a sala/ Do que a luz do refletor/ O cabaré se inflama/ Quando ela dança".

A competência atribuída ao objeto torna-o independente da relação com o sujeito. Essa disponibilidade cria condições para que aquele, devido às modalidades que lhe são atribuídas, desperte o desejo - /querer/- de um outro sujeito "todos": "E com a mesma esperança/ Todos lhe põem o olhar".

O sujeito vê-se obrigado a compartilhar o objeto, no entanto, não há uma efetiva rivalidade, pois ele acredita ser o seu verdadeiro possuidor, mesmo que essa conjunção esteja condicionada a uma temporalidade delimitada: "E eu o dono/ Aqui no meu abandono/ Espero louco de sono/ O cabaret terminar". Essa espera do sujeito revela um estado de insatisfação que não chega a se instituir como sentimento de falta, visto que a espera é resignada.

A narrativa desse estado do sujeito, em um determinado momento, sofre uma fratura: "Rapaz! leve essa mulher contigo/ Disse uma vez um amigo/ Quando nos viu conversar". Esse discurso do interlocutor, que se institui narrativamente como um destinador-manipulador, teria por objetivo despertar o /querer/ do sujeito para que ele executasse um /fazer/ que o levasse à conjunção com o objeto: "Vá construir o seu lar".

No entanto, a /parada/ instituída por esse discurso, sofre também uma /parada/: "Palavra, quase aceitei o conselho/ O mundo, esse grande espelho,/ Que me fez pensar assim". Ela promove a retomada do estado de resignação, e as figuras presentes no discurso do sujeito justificam a opção por esse estado: "Ela nasceu com o destino da lua/ Pra todos que andam na rua/ não vai viver só pra mim”.

O sujeito sabe que a posse é impossível, pois o objeto possui uma competência que o impossibilita de se tornar exclusividade de um só sujeito. Assim, a única saída encontrada é a duração de um estado de insatisfação, no qual o sujeito aguarda resignado a oportunidade de uma nova conjunção.

O aspecto melódico dessa canção é bastante rico e apresenta soluções interessantes em sua progressão. Ele se caracteriza pelo alongamento das vogais presentes na sílaba tônica das palavras, em um percurso melódico que se estabelece por um movimento oscilatório de ascendência/descendência. 
Para critérios de análise, podemos dividir a melodia em duas partes. A primeira corresponde à estetização do objeto e à confirmação da disjunção, cujo desenho melódico investe nas oscilações de altura. No aspecto intenso, a duração longa de algumas notas vocálicas determina o sentido melódico, enquanto a duração curta de outras apenas estabelece o percurso que conduz à vogal tônica. Os dois saltos ascendentes aceleram a melodia, encurtando o percurso para a nota de apoio, mas são rapidamente envolvidos pela gradação descendente que os segue.

Na segunda parte da canção, todo o restante, a progressão melódica também é determinada pela sustentação das vogais em uma progressão que explora o aspecto fonético desses sons e estabelece uma relação direta com o percurso fórico.

Partindo das propostas de Saussure (1975), a silabação é determinada por sons que se abrem e se fecham, constituindo respectivamente um movimento de explosão e implosão, dependendo do contexto em que se encontram. Por exemplo, um "u" seguido de "a" é explosivo $(u<a)$, e um "u" seguido de " $t$ " é implosivo $(u>t)$.

Esse conceito é retomado por Hjelmslev (1985). Tendo em vista o plano extenso, esse linguista propõe o acento como uma modulação entoativa que estabelece o fraseado prosódico por meio de uma relação de pressuposições (ascendência-descendência).

Nessa linha de pensamento, chegamos até Zilberberg (1988) que fez a passagem desse raciocínio da dimensão linguística para a dimensão semiótica ao propor o conceito de "função" como capacidade de interação de um elemento com outros dentro da cadeia sintagmática. A pressuposição é compreendida como a eterna busca do valor ausente. A modulação entoativa rege uma sequência de acentos em uma relação de pressuposição, como em uma narrativa em que o sentimento de falta pressupõe a perda do objeto e a busca pressupõe a sua ausência. Esse movimento corresponderia à progressão contínua do fluxo fórico que dá movimento à cadeia sonora. Esse movimento institui os aspectos incoativos e terminativos (demarcações) pela fronteira silábica (implosão/explosão - ><), e os aspectos durativos (segmentações) pelo ponto vocálico explosão/implosão - <>).

Tendo em vista esses aspectos, na segunda parte da canção notamos primeiramente a duração da vogal "o", a que chamaremos de fechada, tendo em vista o contexto melódico. Ela é sustentada no ponto extremo de cada curva melódica, determinando um fazer remissivo que, narrativamente, corresponde à disjunção do sujeito com o objeto.

Esse percurso estabelece uma gradação ascendente que caminha para a explosão na vogal "a", permitindo a abertura para os valores emissivos, instituindo uma /parada da parada/. Por meio de um recurso fonético e melódico, a vogal expande-se em um eco, abrindo ainda mais a explosão, no instante em que se revela, na letra, a possibilidade de uma conjunção efetiva, relatada em uma gradação descendente que compensa a aceleração anterior.

Os valores emissivos, presentes na tentativa de manipulação do amigo, refletem-se na conservação da vogal "a" no percurso melódico, que é uma repetição daquele em que a vogal "o" predominava. Apesar de as linhas melódicas serem semelhantes, os valores investidos são diferentes, pois anteriormente os remissivos predominavam e agora os emissivos são dominantes. Novamente a melodia caminha para a região aguda, só que agora é instituída uma /parada da parada/, ou seja, a negação do vínculo fiduciário com o destinador, fazendo retornarem os valores remissivos. 
A asseveração final justifica a opção do sujeito pela espera resignada. A volta dos valores remissivos corresponde, na melodia, a uma implosão $(<>)$, na qual a vogal "u" é sustentada, confirmando a opção do sujeito pela duração de seu estado de resignação.

\subsection{A MÁGOA}

Como vimos, a duração da insatisfação e a sua atenuação podem ser figurativizadas pela resignação, paixão que constitui um desvio no percurso passional, por não permitir o estabelecimento do sentimento de falta. Uma outra possibilidade de a falta não se instituir é o prolongamento de uma decepção, que caracteriza um estado de mágoa: "Sentimento ou impressão desagradável causada por ofensa ou desconsideração", segundo o Novo Dicionário Aurélio. Não podemos deixar de levar em conta que a mágoa tem como princípio uma "desconsideração" por parte de um outro sujeito, fato que não possibilita uma atenuação da decepção; pelo contrário, constitui um agravante que se perpetua na duração desse sentimento, como podemos ver na canção "Atiraste uma pedra" (1958), de Herivelto Martins.

\section{ATIRASTE UMA PEDRA}

Atiraste uma pedra no peito de quem

Só te fez tanto bem

E quebraste um telhado

Perdeste um abrigo

Feriste um amigo

\section{Conseguiste magoar}

Quem das mágoas te livrou

Atiraste uma pedra

Com as mãos que esta boca

Tantas vezes beijou

Quebraste o telhado

Que nas noites de frio

Te servia de abrigo

Perdeste um amigo

Que os teus erros não viu

E o teu pranto enxugou

Mas acima de tudo

Atiraste uma pedra

Turvando esta água

Esta água que um dia

Por estranha ironia

Tua sede matou 
O elemento que origina o estado do sujeito é o rompimento de um contrato fiduciário, figurativizado pela expressão "Atiraste uma pedra". O sujeito (S1) vivia uma espera fiduciária, crendo que um outro sujeito (S2) mantivesse a sua conjunção com o objeto (nessa estrutura narrativa, S2 está em sincretismo com o objeto): S1 crer S2 deverfazer $(\mathrm{S} 1 \cap \mathrm{Ov})$.

Porém isso não acontece e S2 rompe o contrato fiduciário. Ocorre, assim, uma fratura, que não afeta apenas a junção, mas as próprias modalidades de S1. O sujeito sofre uma decepção e passa a viver um estado de descontentamento, que é o pivô passional para a elaboração de um programa narrativo de compensação da falta. Entretanto, o sujeito não o realiza, contendo a sua paixão em forma de mágoa (GREIMAS, 1983, p.235).

O que possibilitou o objeto transformar-se em sujeito e consequentemente romper o contrato fiduciário foram as modalidades atribuídas a ele pelo próprio S1. S2 vivia um estado passional figurativizado também como mágoa e S1 deu a ele condições para sair desse estado. Esse fato é apresentado na canção como justificativa de S1 para a confiança depositada em S2.

$\mathrm{S} 1$ não decepcionou S2, pelo contrário, deu-lhe amparo e esperava de S2 uma retribuição, instituindo-lhe, assim, um dever-fazer. Contudo S2 contraria as suas expectativas, rompendo o contrato fiduciário, que na verdade era um simulacro de $\mathrm{S} 1$.

Notamos, assim, a existência de três percursos na canção: um anterior, que denominaremos amparo, a desconsideração, que figurativiza a quebra do contrato fiduciário, e a mágoa que S1 vive. A passagem "Atiraste uma pedra" figurativiza o percurso da desconsideração e "no peito de quem só te fez tanto bem" o do amparo.

No início da melodia, notamos uma gradação ascendente realizada por graus imediatos, compensada por uma gradação descendente em pequenos intervalos. Essa oposição deve-se aos valores investidos em cada frase melódica. Na primeira, remissivos, na seguinte, emissivos. Esse contraste é a célula principal do percurso melódico.

Esse motivo se repete em toda a primeira parte da canção. Após aquela gradação descendente, há uma gradação ascendente que apresenta mais uma vez o percurso da desconsideração. A atitude de S2 é agora figurativizada pela forma verbal "quebraste" e o alvo da ação é "o telhado", que corresponde ao amparo dado por S1. A princípio, a gradação ascendente é similar à anterior, porém ela expande-se para um patamar melódico mais agudo, enfatizando o percurso da desconsideração que tem como consequência a não-conjunção: "Perdeste um amigo".

Novamente, porém explorando a região mais aguda, a ascendência melódica apresenta o percurso da desconsideração. $\mathrm{O}$ ato em si aparece na passagem "Conseguiste magoar" que expõe a paixão vivida atualmente pelo sujeito, a mágoa.

Esse estado passional aparece também no percurso do amparo - "quem das mágoas te livrou". Porém, ao se referir ao percurso da desconsideração, o termo aparece em uma linha melódica ascendente e, no outro caso, no sentido descendente, enfatizando a oposição dos percursos.

A partir daí, ocorre uma extensa gradação descendente que repete o contraste melódico ascendência/descendência. Convém ressaltar a repetição da passagem "Atiraste uma pedra" e a ênfase dada à desconsideração na passagem "com as mãos que essa boca tantas vezes beijou" em uma asseveração que confirma a decepção do sujeito. 
Na segunda parte da canção, vemos que o percurso da desconsideração "Quebraste o telhado" - já aparece na nota mais aguda da tessitura, realizando uma transposição e dispensando a gradação ascendente, o que acelera a melodia; e o do amparo em uma gradação descendente que retoma a desaceleração.

Esse percurso melódico é repetido logo a seguir, mas agora prepara a descendência final em uma gradação. Essa gradação apresenta elementos figurativos importantes. Destacamos primeiramente a repetição da passagem "Atiraste uma pedra" enfatizada pela expressão "Mas acima de tudo". Isso enfatiza que o elemento determinante do estado passional de $\mathrm{S} 1$ é a desconsideração.

A parábola "Turvando esta água/ Esta água que um dia/Por estranha ironia/ Tua sede matou" resume todo o percurso passional de S1. O termo "água" figurativiza o estado anterior de $\mathrm{S} 1$, o percurso temático da desconsideração está presente na forma verbal "turvando", o estado de S2 é representado pelo termo "sede" e o percurso do amparo aparece na passagem "Tua sede matou".

O aspecto principal do percurso passional do sujeito é o conflito entre o amparo e a desconsideração que reflete uma oposição no nível fundamental entre emissivo e remissivo, porém prevalecendo os valores remissivos - "Mas acima de tudo / Atiraste uma pedra". Essa contraposição de valores instrui o aspecto melódico determinando a oscilação ascendência-descendência, repetida várias vezes. A opção pelos valores remissivos determina a desaceleração da melodia, que faz durar o estado passional do sujeito, a mágoa.

\section{A VINGANÇA}

Com base na sequência passional que vimos trabalhando, percebemos nos tópicos anteriores (resignação e mágoa) que o sentimento de falta pode não se efetivar devido à duração da insatisfação ou da decepção, provocando um desvio no percurso passional. Não havendo essa resolução, a falta se estabelece e consequentemente a necessidade de sua liquidação.

A vingança representa um programa narrativo de liquidação da falta fiduciária. $\mathrm{O}$ sujeito, modalizado por um /crer/, institui um /dever/ a outro sujeito que, por seu lado, rompe esse contrato fiduciário, originando uma frustração. Estabelecido o sentimento de falta, o sujeito é modalizado por um /querer/ e um /poder/ compensar essa fratura fiduciária.

Com a análise de "Vingança" (1972), de Lupicínio Rodrigues, buscaremos compreender como essa paixão é abordada nessa canção que representa um dos pontos de maior dramaticidade dentro do samba-canção.

\section{VINGANÇA}

Eu gostei tanto

Tanto quando me contaram

Que lhe encontraram

Bebendo, chorando

Na mesa de um bar 
E que quando os amigos do peito

Por mim perguntaram

Um soluço cortou sua voz

Não lhe deixou falar.

Eu gostei tanto

Tanto quando me contaram

Que tive mesmo de fazer esforço

Pra ninguém notar.

O remorso talvez seja a causa

Do seu desespero

Ela deve estar bem consciente

Do que praticou,

Me fazer passar tanta vergonha

Com um companheiro

E a vergonha

É a herança maior que meu pai me deixou.

Mas enquanto houver voz em meu peito

Eu não quero mais nada

Só vingança, vingança, vingança

Aos santos clamar

Ela há de rolar como as pedras

Que rolam na estrada

Sem ter nunca um cantinho de seu

Pra poder descansar

Inicialmente o enunciador, que está em sincretismo com o sujeito passional (S1), demonstra a sua satisfação - "Eu gostei tanto/ Tanto quando me contaram"- ao saber que um outro sujeito (S2) está sofrendo - "Bebendo, chorando/Na mesa de um bar".

Essas informações todas fazem com que nos perguntemos quais foram as causas que conduziram o sujeito a esse estado passional, ou seja, por que ele sente tanto prazer em ver outra pessoa sofrendo?

Greimas (1983, p.23) mostra que a vingança é um reequilíbrio de sofrimentos entre sujeitos antagonistas. O prazer sentido pelo vingador é resultado de uma sequência passional que se aproxima do modelo do sadismo (sofrer - fazer sofrer - experimentar o prazer). Nessa canção, vemos que o sujeito não faz sofrer. Sabendo que o outro sujeito sofre, vive esse prazer.

O componente melódico nessa passagem investe nas oscilações de altura e valoriza alguns saltos. Notemos o trabalho que o enunciador realiza com o segmento "Eu gostei tanto/ Tanto quando me contaram", cuja repetição enfatiza o sentimento de prazer.

A seguir, partindo da nota mais aguda da tessitura, a melodia descreve uma gradação descendente regida pela previsibilidade dos graus que são valorizados pela sustentação de algumas notas. Essa gradação compensa, tanto na melodia quanto na letra, a aceleração anterior, pois ela traz a justificativa para o estado passional apresentado e 
desacelera a melodia. A nota mais aguda, que corresponde ao primeiro patamar da gradação, expõe o remorso como causador do sofrimento de $\mathrm{S} 2$, devido à consciência de ter cometido uma falta grave - "Me fazer passar tanta vergonha" -, vergonha essa que é valorizada, no último estágio dessa extensa gradação, por ser herança paterna.

Notamos que essa passagem possui uma narratividade bastante rica e complexa, pois ela sintetiza todo o percurso passional que vimos trabalhando até aqui. Para que possamos compreender melhor as relações sintáticas dessa narrativa, buscaremos recompor todo o percurso do sujeito que o levou ao desejo de vingança.

$\mathrm{S} 1$ vivia uma espera fiduciária, pois estava relacionado a S2 pelo /crer/ e atribuindolhe um /dever-fazer/, modalidade que, neste caso, não se limita a realizar a conjunção, mas perpetuá-la. No entanto, S2 contraria as expectativas de $\mathrm{S} 1$ e rompe esse contrato fiduciário, ao fazê-lo passar tanta vergonha, violando as regras impostas pelo /dever/. Assim, S1 sofre uma decepção e passa a viver um sentimento de falta fiduciária. $\mathrm{O}$ rompimento da relação fiduciária origina as relações polêmicas na narrativa e S2 adquire o estatuto de anti-sujeito ${ }^{4}$. Essa fratura estabelece para os dois actantes programas narrativos antagônicos: de um lado, vemos o percurso de S1 que estaria em busca de uma compensação da falta, no caso a vingança; e de outro o percurso do anti-sujeito que se iniciou no momento da ruptura fiduciária e resultou em sofrimento, devido ao remorso. Essa paixão, que estudaremos com maiores detalhes a seguir, consiste em uma sanção negativa do próprio percurso, no qual o sujeito, modalizado pelo /saber/ - "Você deve estar consciente" - instaura-se como destinador-julgador.

$\mathrm{O}$ que originou toda a narrativa foi o /fazer/ de S2 - "Me fazer passar tanta vergonha". A gravidade desse ato deve-se ao valor que S1 dava à sua honra - "E a vergonha é a herança maior que meu pai me deixou" - que foi maculada frente a seu grupo social. Por esse caminho, retornamos ao ensaio de Greimas (1983) que coloca a questão de l'honneur blessé como ponto determinante para o desejo de vingança. A agressão à honra é uma ofensa que pede uma reparação, nesse caso, em forma de vingança, como uma compensação moral do ofendido em função da punição do ofensor. Vimos que, nessa canção, a ofensa de S2 é compensada pelo fato de S1 saber que S2 está sofrendo, e mais do que isso, esse sofrimento é presenciado por seu grupo social ${ }^{5}$.

A partir da sequência passional depreendida, não podemos deixar de perceber que os actantes possuem percursos passionais opostos, mas que se relacionam dialeticamente. A fratura fiduciária pode ser compreendida, utilizando os conceitos de Zilberberg (1988), como um anti-programa narrativo que determinou uma /parada/ e instituiu um outro percurso de um anti-sujeito. Essa descontinuidade é responsável pela presença dos valores remissivos no percurso passional de S1. A continuidade só é retomada quando os valores remissivos passam a instruir o percurso do anti-sujeito e os valores emissivos o de S1. Essa compensação estabelece no plano discursivo a isotopia que figurativiza o prazer de S1 ao sentir-se vingado.

\footnotetext{
4 "[...] o espaço fiduciário [...] forneceria um ponto de partida conveniente para a comunicação contratual dos objetos; uma modulação do devir, afetando a fidúcia, conviria para explicar a aparição das relações polêmicas ..." (GREIMAS; FONTANILLE, 1993, p. 49).

${ }^{5}$ Vejamos que existem outras formas de compensar a ofensa, como nos mostra Greimas, em Le défi (1983, p. 213). O duelo é um desses reguladores e, nesse caso, os universos da vergonha e do medo estão relacionados, já que ao ser desafiado para um duelo, ter medo seria motivo de vergonha.
} 
Essa última parte da canção, que repete a gradação, deixa evidente que o objetivo de S1 é único: o sofrimento do anti-sujeito. A ênfase dada ao termo "vingança" espelha a intensidade do /querer/ do sujeito; porém, o que faz durar esse desejo de vingança é a força que ele possui, ou seja, um /poder-fazer/ que se efetiva em virtude do eterno sofrimento do anti-sujeito. Essas duas gradações possuem o mesmo desenho melódico, regido por uma previsibilidade de graus, isto é, há uma lei que as organiza. Em um primeiro momento, essa lei recupera passo a passo o percurso passional da relação S1/S2. Já na segunda execução, essa lei organiza não uma memória, mas uma expectativa passional para a concretização da vingança - "Ela há de rolar como as pedras/ que rolam na estrada/ sem ter nunca um cantinho de seu/ pra poder descansar".

Assim, os valores emissivos continuariam a determinar o percurso de S1 e os remissivos o do anti-sujeito. Essa oposição, determinada pela duração, restabeleceria a continuidade do percurso de S1, compensando por vingança o seu sentimento de falta.

\section{CASTIGO}

Definido como "pena recebida por um erro cometido", o castigo apresenta um /fazer/ inicial, que vem a ser o ato de um sujeito, e um /fazer/ final, que seria a punição aplicada por outro sujeito. Tratado enquanto percurso passional, ele revela uma sequência de ações e estados que o institui como um regulador da tensividade passional que rege a relação entre dois sujeitos. Será feita agora uma análise da canção "Castigo" (1978), de Lupicínio Rodrigues e Alcides Gonçalves, que retrata a atitude tomada por um sujeito frente ao retorno de um anti-sujeito.

\section{Castigo}

Eu sabia que você um dia

Me procuraria em busca de paz

Muito remorso, muita saudade

Mas, afinal, o que é que lhe traz

A mulher quando é moça e bonita

Nunca acredita em poder tropeçar

Quando os espelhos lhe dão conselhos

É que procuram em quem se agarrar

E você pra mim foi uma delas

Que no tempo em que eram belas

Viam tudo diferente do que é

E agora que não mais encanta

Procura imitar a planta

As plantas que morrem de pé

E eu lhe agradeço por de mim ter se lembrado

Que entretanto desgraçado

Que em sua vida passou

Homem que é homem

Faz qual o cedro que perfuma o machado

Que o derrubou 
Essa canção revela um sujeito (S1) que assume a posição de destinador-julgador e faz um balanço retrospectivo do percurso de um anti-sujeito, instituído no momento de uma separação pressuposta. As figuras presentes no componente linguístico deixam perceber que o percurso desse anti-sujeito é determinado pelos valores remissivos: o remorso, sanção negativa do próprio percurso; a saudade, um sentimento de falta; o orgulho, valorização da própria competência - "A mulher quando é moça e bonita" -, em oposição à perda dessa competência - "Quando os espelhos lhe dão conselhos" -; todos esses estados têm como consequência a volta em busca de uma estabilidade passional "paz".

Por outro lado, os valores emissivos orientam o percurso de S1. Se a partida constitui-se do seu ponto de vista como uma /parada/ que fraturou a relação entre os sujeitos, o retorno corresponde a uma /parada da parada/. Além disso, esses valores são enfatizados pela confirmação do /saber/ de S1 de que o percurso do anti-sujeito teria como resultado a volta.

O percurso melódico da primeira parte da canção é orientado pelos valores remissivos. Ele explora a extensão melódica por meio da duração das notas, do contraste de alturas e das grandes curvas constituídas por saltos e gradações em uma sequência ascendência/descendência. Nesse contexto, destacam-se alguns recursos que dão um tratamento específico à tensividade passional.

A confirmação do /saber/ de S1, expressa em um salto ascendente, abre a canção, enfatizando os valores emissivos que orientam o seu percurso. No entanto, a progressão melódica é determinada, nessa primeira parte, pelos valores remissivos presentes no percurso do anti-sujeito, deixando os emissivos na berlinda, os quais serão explorados na segunda parte da canção.

Após um outro salto até a nota mais aguda da tessitura, a melodia descreve, no regime extenso, uma longa gradação descendente até repousar na região grave, em que o componente linguístico assevera o resultado do percurso do anti-sujeito, já previsto pelo sujeito: a volta.

A progressão discursiva da primeira parte da canção revela na relação entre a letra e a melodia uma compatibilidade tensiva que vai se acentuando à medida que o tempo decorre. A melodia descreve uma sequência de gradações ascendentes e saltos descendentes que determinam, no regime extenso, uma gradação até a região aguda da tessitura. Nesse ponto, é relatada, como consequência desse acúmulo tensivo, a volta em busca de estabilização passional. Esse percurso melódico é realizado duas vezes nessa primeira parte da canção e as figuras do componente linguístico, nas duas oportunidades, exprimem a presença dos valores remissivos no percurso passional do anti-sujeito.

Na segunda parte da canção, emerge o fazer emissivo que determina o percurso de S1. Nesse momento, a melodia passa a explorar a estratégia persuasiva da tematização que, por meio da repetição dos motivos, controla a velocidade e evita a dispersão do núcleo melódico. Com esse recurso, o compromisso com o fazer emissivo, determinado por uma /parada da parada/ que restabelece a continuidade do percurso de S1, fica assegurado. 
No entanto, a coesão do núcleo melódico é rompida logo a seguir, quando a melodia passa explorar novamente a extensão vertical da tessitura por meio de grandes curvas melódicas que exploram outras regiões da tessitura. Embora a isotopia figurativa presente na letra esteja recobrindo os valores remissivos inerentes ao percurso do anti-sujeito - "E agora que não mais encanta/ Procura imitar a planta/ As plantas que morrem de pé" -, pode-se deduzir por oposição que os valores emissivos estejam conduzindo o percurso de S1.

O embate entre esses valores pode ser percebido na relação de dominância e recessividade entre o fazer emissivo e o remissivo que determina a orientação do percurso melódico dessa segunda parte da canção.

A última isotopia figurativa é expressa por uma gradação ascendente, seguida de uma extensa descendência melódica que finaliza a canção e assevera o momento efetivo da sanção realizada por S2, instituído como destinador-julgador do percurso do antisujeito: "Homem que é homem/ Faz qual o cedro que perfuma o machado/ Que o derrubou". O termo "cedro" figurativiza o sujeito e "machado", o anti-sujeito. Derrubar o cedro é o anti-programa que estabelece as relações polêmicas na narrativa. Os percursos do sujeito e do anti-sujeito prosseguem paralelamente em uma relação una e antagonista em que o êxito de um, determinado pelo fazer emissivo, pressupõe o fracasso do outro, orientado pelo fazer remissivo.

O discurso do destinador-julgador tem como objetivo reconhecer o percurso de S1 como vitorioso. A sanção não se institui em uma dimensão somática, pois não é estabelecido um programa narrativo de punição, mas sim em uma dimensão cognitiva (GREIMAS, 1983), em que o /saber/ a respeito do fracasso do percurso do anti-sujeito e, mais do que isso, a sua remissão por meio da volta já determinam uma punição figurativizada no título da canção: "Castigo".

Os valores emissivos presentes no percurso de $\mathrm{S} 1$ são enfatizados pelo seu orgulho - "Homem que é homem" - de poder optar por uma não punição do anti-sujeito. Essa sanção figurativizada pela forma verbal "perfuma" só é possível devido ao reequilíbrio de valores já estabelecido pelo castigo: o percurso de S1 determinado pelos emissivos e o de $\mathrm{S} 2$ pelos remissivos.

Com a análise dessa canção, pudemos ter uma visão do percurso passional do castigo. A recomposição da sequência de estados /ser/ e percursos narrativos /fazer/ deixa perceber dois percursos passionais, um do sujeito e outro do anti-sujeito, que se relacionam de forma antagônica.

O percurso do anti-sujeito inicia-se por um /fazer/ - partida -, motivado por uma valorização das próprias competências - /ser/ - e orientado por um fazer emissivo. Esse /fazer/ tem como consequência o arrependimento - /ser/ - que leva o anti-sujeito a executar o percurso da volta - /fazer/, determinado por um fazer remissivo. Esse percurso passional já se constitui como castigo.

O reequilíbrio de valores promovido pelo castigo pode ser percebido pelas transformações de estado no percurso passional do sujeito que, no momento da partida do anti-sujeito, é determinado pelos valores remissivos e na volta, pelos emissivos. 
É importante notar a inversão de valores que se estabelece na progressão desses dois percursos passionais. Quando a relação contratual se rompe, o percurso do antisujeito contém os valores emissivos e o do sujeito, os remissivos. Mas, a partir do arrependimento daquele, os valores remissivos invadem o seu percurso, e os emissivos migram para o do sujeito, assim permanecendo até o reencontro final de ambos. Nesse momento, o sujeito, instituído como destinador-julgador de toda sequência passional, opta pela não punição do anti-sujeito, confirmando a presença dos valores emissivos em seu estado final.

\section{CONSIDERAÇÕES FINAIS}

Após desenvolver um modelo de análise da narrativa baseado na modalidade do /fazer/, a semiótica direcionou seus estudos para a modalidade do /ser/, o que significou um investimento na análise das relações passionais no discurso. Esse novo rumo tomado pela teoria semiótica recebeu o nome de "Semiótica das paixões".

$\mathrm{O}$ artigo De la colère, de A. J. Greimas, foi fundamental para o estudo dos percursos passionais, estimulando trabalhos cada vez mais profundos - tendo em vista o percurso gerativo do sentido - sobre os estados passionais do sujeito e possibilitando propostas para a compreensão do percurso fórico que orienta a construção do sentido.

Esses avanços teóricos possibilitaram-nos investir em pesquisas sobre a criação dos efeitos de sentido na canção popular brasileira, tendo em vista a particularidade da canção que reside na compatibilização dos elementos linguísticos e melódicos. No caso específico do samba-canção, os estudos sobre as paixões serviram para compreender a característica específica desse gênero: o investimento nos estados passionais do sujeito.

Como observamos no percurso desenvolvido, inicialmente com as canções "As rosas não falam" (1976), de Cartola, e "Volta" (1978), de Lupicínio Rodrigues, há a presença de um sentimento de falta que pode desencadear programas narrativos de compensação da falta. Entretanto, esse sentimento pode ser atenuado por meio de outros estados passionais como a resignação e a mágoa, representadas respectivamente nas canções "Quem há de dizer" (1972), de Lupicínio Rodrigues, e "Atiraste uma pedra" (1958), de Herivelto Martins. Mantido o sentimento de falta, haverá a necessidade de sua compensação, abrindo espaço para a elaboração do percurso da vingança, como pudemos observar na análise da canção "Vingança" (1972), de Lupicínio Rodrigues. Outro regulador passional para esse sentimento de falta seria o castigo, um percurso de sanção punitiva figurativizado na canção “Castigo” (1978), também de Lupicínio Rodrigues.

A estratégia de tomar o percurso passional da cólera como orientação para este artigo revelou-se bastante produtiva, pois nos foi possível compreender como são constituídos os estados passionais do sujeito no cancioneiro do samba-canção, preservando o princípio que orientou o ensaio De la colère, de Greimas: o encadeamento dos estados passionais, compreendido como um percurso semiótico. 
CARTOLA. As rosas não falam. Um mundo melhor. Intérprete: Beth Carvalho. RCA Victor, 1976. LP. FONTANILLE, J. Le tumulte modal: de la macro-syntaxe à la micro-syntaxe passionnelle. Actes Sémiotiques. Paris: Bulletin, v. 11, n. 39, 1986. p. 12-31.

GREIMAS, A. J. De la colère: étude de sémantique lexicale. Du sens II. Paris: Seuil, 1983. p. 225-239. GREIMAS, A. J. De la nostalgie: étude de sémantique lexicale. Annexes des Cahiers de linguistique hispanique médiévale, v. 7, 1988. Hommage à Bernard Pottier. p. 343-349.

GREIMAS, A. J.; FONTANILLE, J. Sémiotique des passions. Paris: Seuil,1991.

GREIMAS, A. J.; FONTANILLE, J. Semiótica das paixões. São Paulo: Ática, 1993.

HJELMSLEV, L. Nouveaux essais. Paris, PUF,1985.

HERIVELTO, M. Atiraste uma pedra. Escultura. Intérprete: Nelson Gonçalves. RCA Victor, 1958. LP. LOPES, E. Paixões no espelho: sujeito e objeto como investimentos passionais primordiais. Cruzeiro semiótico ("Semiótica das paixões"). Porto: Associação portuguesa de Semiótica, 1989/1990. p.154-160. RODRIGUES, L. Vingança. Jamelão Interpreta Lupicínio Rodrigues. Intérprete: Jamelão. Continental, 1972. LP.

RODRIGUES, L. Volta. Homenagem a Lupicínio Rodrigues. Intérprete: Linda Batista. Som Livre, 1978. LP.

RODRIGUES, L; GONÇALVES, A. Quem há de dizer. Jamelão Interpreta Lupicínio Rodrigues. Intérprete: Jamelão. Continental, 1972. LP.

RODRIGUES, L; GONÇALVES, A. Castigo. Homenagem a Lupicínio Rodrigues. Intérprete: Gilberto Milfont. Som Livre, 1978. LP.

SAUSSURE, F. Cours de Linguistique générale. Paris: Payot, 1975.

TATIT, L. O cancionista: composição de canções no Brasil. São Paulo: Edusp, 1996.

TATIT, L.; LOPES, I. C. Elos de melodia e letra: análise semiótica de seis canções. Cotia, SP: Ateliê Editorial: 2008.

ZILBERBERG, C. Pour introduire le faire missif. Raison et poétique du sens. Paris: PUF, 1988.

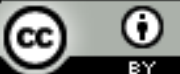

Este texto está licenciado com uma Licença Creative Commons Atribuição 4.0 Internacional. 